Sains Malaysiana 50(8)(2021): 2293-2308

http://doi.org/10.17576/jsm-2021-5008-13

\title{
Effects of Acacia Honey Drink After Exercise-Induced Dehydration on Selected Physiological Parameters and Subsequent Running Performance
}

(Kesan Minuman Madu Akasia Selepas Pendehidratan Aruhan-Senaman pada Parameter Fisiologi Terpilih dan Seterusnya Prestasi Larian)

\author{
Aidi-Naim Mohamad Samsani, Foong Kiew OoI*, Chee Keong Chen \& Mohamed SaAt Ismail
}

\begin{abstract}
This study examined the effect of honey supplementation on exercise performance and biochemical markers in comparison to plain water and sports drink in the heat. Ten recreational athletes (Age: $22.2 \pm 2.0$ years, weight: $65.7 \pm$ $5.3 \mathrm{~kg}$; height: $\left.170.4 \pm 3.5 \mathrm{~cm} ; V_{2}: 51.5 \pm 3.7 \mathrm{~mL} . \mathrm{kg}^{-1} . \mathrm{min}^{-1}\right)$ participated in this study. Participants ran at $70 \%$ of their $V O_{2 \max }$ for $1 \mathrm{~h}$ in a pre-load phase (Run-1), followed by a rehydration phase for $2 \mathrm{~h}$ and then a 20 min self-paced time trial (Run-2). After Run-1, participants drank either Acacia honey, sports drink or plain water with an amount equivalent to $150 \%$ of body weight loss. Subsequently, the participants performed the 20 min self-paced time trial. Acacia honey elicited an improved running time trial performance with a significantly $(p<0.05)$ longer distance ran compared to plain water trial, but it was not different from the sports drink trial. In addition, there was no significant difference in running performance between sports drink and plain water trials. Plasma glucose, insulin and free fatty acids were significantly $(p<0.05)$ higher in $H$ and sports drink compared to the $W$ trial during the rehydration phase. There were no significant differences in body weight changes, oxygen uptake, heart rate, rate of perceived exertion, tympanic temperature, plasma volume changes, plasma cortisol, urine osmolality, volume, and specific gravity among the three trials. Thus, Acacia honey can be recommended to be used as a rehydration drink for individuals who train and compete in the heat.
\end{abstract}

Keywords: Acacia honey; heat; rehydration; running performance; urine osmolality

\section{ABSTRAK}

Penyelidikan ini mengkaji kesan madu sebagai diet tambahan terhadap prestasi senaman dan penanda biokimia berbanding dengan air kosong dan minuman sukan dalam persekitaran panas. Sepuluh atlet rekreasi (Umur: $22.2 \pm$ 2.0 tahun; berat: $65.7 \pm 5.3 \mathrm{~kg}$; ketinggian: $\left.170.4 \pm 3.5 \mathrm{sm} ; V_{2 m a x}: 51.5 \pm 3.7 \mathrm{~mL} \mathrm{~kg}^{-1} . \mathrm{min}^{-1}\right)$ mengambil bahagian dalam kajian ini. Para peserta berlari pada 70\% VO ${ }_{2 \max }$ mereka selama 1 jam dalam fasa pra-muat (Larian-1), diikuti dengan fasa rehidrasi selama 2 jam dan kemudian larian rentak-sendiri selama 20 min (Larian-2). Selepas Larian-1, peserta meminum madu Acacia, minuman sukan atau air kosong dengan jumlah yang setara dengan 150\% penurunan berat badan. Selepas itu, para peserta melakukan percubaan masa rentak-sendiri selama 20 min. Madu Acacia menghasilkan prestasi larian percubaan masa yang lebih baik dan jarak yang lebih jauh secara signifikan $(p<0.05)$ berbanding dengan percubaan air kosong. Namun, tidak ada perbezaan yang signifikan dalam prestasi larian antara percubaan minuman sukan dan air kosong. Glukosa, insulin dan asid lemak bebas plasma dalam percubaan madu Acacia dan minuman sukan adalah lebih tinggi secara signifikan $(p<0.05)$ berbanding dengan percubaan air kosong ketika fasa rehidrasi. Tidak ada perbezaan yang signifikan dalam perubahan berat badan, pengambilan oksigen, denyutan jantung, kadar persepsi keletihan, suhu timpanik, perubahan isi padu plasma, kortisol plasma, keosmololan, isi padu dan nilai graviti khusus air kencing antara ketiga-tiga percubaan. Madu Acacia menghasilkan prestasi percubaan masa yang lebih baik berbanding dengan percubaan air tetapi tidak berbeza dengan minuman sukan. Justeru, madu Acacia mungkin berpotensi digunakan sebagai minuman rehidrasi bagi individu yang berlatih dan bertanding dalam persekitaran panas.

Kata kunci: Haba; madu Acacia; osmolaliti air kencing; prestasi larian; rehidrasi 


\section{INTRODUCTION}

Athletes perform physical activities such as training and competing through a range of environmental conditions which include hot and humid environments. Athletes who train in the heat on a daily basis are predisposed to a high risk of dehydration. Hence, proper rehydration is recommended for these individuals to avoid any adverse effects of dehydration. The main aim for adequate rehydration is for restoration of muscle and liver glycogen as well as replacement of body water and electrolytes (Lopez 2012).

During the recovery phase, ingestion of carbohydrate is important to replenish the muscle and liver glycogen. Glycogen is a readily available source of energy for the muscles, and it is crucial for refueling performance during training or competition. The purpose of consuming high carbohydrate drink is to ensure adequate carbohydrate intake and to replenish carbohydrate stores after exhaustive exercise (Jeukendrup 2004). Glycogen depletion and hypoglycemia have been associated with fatigue and decrement in the performance during prolonged exercise (Tsintzas \& Williams 1998). Ingestion of fluid containing carbohydrate is recommended to improve exercise performance as muscle glycogen storage is replenished, and the decline in blood glucose and dehydration can be avoided (Ivy 1999; Murray 1996).

Consuming fluid in direct proportion to sweat loss during rehydration could maintain proper physiological functions and has been shown to significantly improve exercise performance (James et al. 2017). Additionally, restoration of body fluid losses is necessary for optimal cardiovascular function and thermoregulation during subsequent exercise (Takamata et al. 1998). The risks of dehydration on adverse consequences on sports performance such as impaired endurance exercise performance indicated by a shortened time to exhaustion or a reduction in sustainable exercise intensity are welldocumented (Casa et al. 2019). Thus, various types of drinks have been used as rehydration strategies during post-exercise to ensure adequate recovery before the next bout of exercise. These drinks include deep-ocean mineral water (Keen et al. 2016), maple water (Matias et al. 2019) and yogurt drink (Niksefat et al. 2019). Sports drink usually contains 4 to $8 \%$ carbohydrate and electrolytes (Murray 1996). Fluid and electrolyte replacement promote proper rehydration which is important in delaying the onset of fatigue either during exercise, training, or competition (Adams et al. 2019; Casa et al. 2019).
The composition of honey depends primarily on the floral sources. It is a supersaturated sugar which is mainly composed of a complex mixture of carbohydrate and gets its sweetness from the monosaccharides i.e., fructose and glucose, and has approximately the same relative sweetness as that of granulated sugar (Saxena et al. 2010). With respect to carbohydrates, honey contains mainly fructose (about 38.5\%) and glucose (about $31.0 \%$ ). Honey also contains trace amounts of several vitamins and minerals. It also contains tiny amounts of several compounds such as vitamin $\mathrm{C}$ which functions as antioxidants (Gheldof et al. 2002; Martos et al. 2000).

Earnest et al. (2004) investigated the effect of honey gel supplementation during a $64 \mathrm{~km}$ cycling time trial performance. In this study, nine cyclists ingested a gel containing honey, dextrose, and flavored placebo with 250 $\mathrm{mL}$ of water at every $16 \mathrm{~km}$ during a $64 \mathrm{~km}$ time trial. Their results showed that honey and dextrose ingestion elicited shorter cycling time to complete $64 \mathrm{~km}$ compared to placebo. They concluded that honey could serve as a useful alternative form of carbohydrate for enhancing sport performance in athletes. Another study had also compared honey drink with plain water, and it was found that rehydration with honey drink has potential to improve endurance running performance (Ahmad et al. 2015). Nevertheless, to date, study on the comparison between honey drink and a sports drink as a rehydration aid has not been carried out. The purpose of this study was to investigate the effects of honey supplementation on time trial performance and selected physiological parameters compared to a commercially-available sports drink and plain water in the heat. We hypothesized that there was a significant difference in subsequent running performance with post-exercise ingestion of honey drink compared to a commercially-available sports drink or plain water.

\section{MATERIALS AND Methods}

\section{PARTICIPANTS}

Ten recreational male athletes (20 to 30 years old) who performed regular exercise for at least $30 \mathrm{~min}$ per session and more than two times per week (minimum duration of 2 months prior to the study) were recruited. Sample size was calculated by Power and Sample size calculation software (Version 3.0) based on Ooi et al. (2001). Power of the study was set at $80 \%$ with $95 \%$ confidence interval. 
Standard deviation observed was 1.67 and difference in population mean was 1.5 , therefore the effect size (d) used was 0.89 . The calculated sample size was 10 participants per group. All the participants were able to run on motorized treadmill at $70 \%$ of their respective maximal oxygen uptake $\left(\mathrm{VO}_{2 \max }\right)$ for at least $60 \mathrm{~min}$. Participants who fulfilled the inclusion criteria provided their written informed consent. The exclusion criteria were individuals having any acute and chronic diseases such as asthma, stroke, diabetes and heart problems. This counter-balanced, crossover study was approved by the Human Research Ethics Committee, Universiti Sains Malaysia (USMKK/ PPP/JEPeM [239.3(14)]).

\section{PRELIMINARY TRIALS}

This study was conducted at the Exercise and Sports Science Laboratory, School of Health Sciences, Universiti Sains Malaysia. The following preliminary tests were conducted before the main experimental trials: A $16 \mathrm{~min}$ incremental sub-maximal running test to establish the relationship between running speed and oxygen uptake $\left(\mathrm{VO}_{2}\right)$; and A graded maximal treadmill running test to exhaustion to determine each participant's $\mathrm{VO}_{2 \max }$ (Keong et al. 2006; Muhammad et al. 2018; Wee et al. 1999).

\section{SUB-MAXIMAL TEST}

Prior to this test, participants were fitted with heart rate monitor, head gear, mouth piece and nose clip. The participants were required to run on the treadmill with an initial speed set at $6 \mathrm{~km} \cdot \mathrm{h}^{-1}$. At the end of each 4 min stages, the speed was increased by $1 \mathrm{~km} \cdot \mathrm{h}^{-1}$ until the speed of $9 \mathrm{~km} \cdot \mathrm{h}^{-1}$ was achieved. Expired air was analyzed for oxygen consumption via gas analyzer (VMax Spectra, USA). In addition, heart rates were also recorded throughout the test. The oxygen uptake during the final minute of each 4 min increment was recorded. Then, the running speed for the warm-up at $50 \% \mathrm{VO}_{2 \max }$ and endurance running performance at $70 \% \mathrm{VO}_{2 \max }$ for each participant was estimated from the plot of a graph with oxygen consumption versus the four speeds ran during this submaximal test (Wilmore et al. 1998).

\section{MAXIMAL OXYGEN UPTAKE $\left(\mathrm{VO}_{2 \max }\right)$ TEST}

The $\mathrm{VO}_{2 \max }$ test required the participants to run until exhaustion at a constant speed while the inclination was increased. During the test, inclination of treadmill was increased by $2.5^{\circ}$ for every 3 min starting from the initial inclination of $3.5^{\circ}$. The set up for the participants was similar with the sub maximal test. At every $20 \mathrm{~s}$, the expired air was analyzed by the gas analyzer (VMax Spectra, USA). Heart rate and rate of perceive exertion (RPE) were also taken during the last $20 \mathrm{~s}$ of each incremental stage. The test was terminated when participants could no longer run despite verbal encouragement. The value of $\mathrm{VO}_{2 \mathrm{~m}}$ was accepted when the participants achieved 3 out of the following 4 criteria: a $\mathrm{VO}_{2}$ leveling off; Respiratory exchange ratio of more than 1.15 ; heart rate more that $95 \%$ of age-predicted $\mathrm{HR}_{\max }$; and RPE of more than 18 Borg's unit (Edvardsen et al. 2014).

\section{FAMILIARIZATION WITH THE EXPERIMENTAL TRIALS}

A familiarization trial was carried out to familiarize the participants with the intensity and environmental condition of the main experimental trials. Participants were required to run on the treadmill at $70 \%$ of their respective $\mathrm{VO}_{2 \max }$ for $60 \mathrm{~min}$ in the heat $\left(31^{\circ} \mathrm{C}, 70 \%\right.$ relative humidity). Running speed during warm up and endurance running was determined from the data obtained from the preliminary trials. Participants who were unable to run at $70 \%$ of their $\mathrm{VO}_{2 \max }$ for at least $60 \mathrm{~min}$ were excluded from the study.

\section{HONEY AND SPORTS DRINK}

Acacia honey which was used in the present study originated from the state of Johor in Malaysia. Acacia honey is produced by bees known as Apis mellifera which collects their nectar from wild Acacia leaves (Khalil et al. 2011). Based on the analysis made by the Laboratory of Department of Molecular Medicine, Universiti Malaya, Acacia honey used in the present study contains fructose, glucose, sucrose, and maltose. Each $100 \mathrm{~mL}$ of Acacia honey contains $302 \mathrm{kcal}$ of energy, $75 \mathrm{~g}$ carbohydrate, $31.2 \mathrm{~g}$ fructose, $22.9 \mathrm{~g}$ glucose, $9.9 \mathrm{~g}$ sucrose, $3.3 \mathrm{~g}$ maltose, $13 \mathrm{mg}$ sodium and $0.5 \mathrm{~g}$ protein (Ahmad et al. 2020). The commercially available sports drink contains $20 \mathrm{kcal}$ energy, $4.9 \mathrm{~g}$ carbohydrate, $42 \mathrm{mg}$ sodium, 19 $\mathrm{mg}$ potassium, $4 \mathrm{mg}$ calcium, $40 \mathrm{mg}$ chloride and $17 \mathrm{mg}$ phosphate for every $100 \mathrm{~mL}$.

\section{MAIN EXPERIMENTAL TRIALS}

The participants were required to perform three main trials (Run-2) after ingestion of either honey drink, 
sports drink or plain water during the rehydration period. These three trials were counter-balanced and carried out one week apart. On each day of the experimental trials, participants reported to the laboratory after $10 \mathrm{~h}$ of overnight fast. The following procedures were carried out just before the commencement of the trial: A standardized breakfast with one piece of bread and $500 \mathrm{~mL}$ of plain water; Measurement of nude body mass; Urine sample collection; Cannulation at the forearm vein to make repeated withdrawal of blood samples. To minimize differences in resting muscle glycogen concentrations between trials, participants recorded their food intake for three days prior to the first experimental trial in a food diary. They were then instructed to follow the same diet before the second and third trials.

\section{PRE-LOAD PHASE (RUN-1)}

For Run-1, the participants were required to run on a treadmill in the heat $\left(31^{\circ} \mathrm{C}, 70 \%\right.$ relative humidity) at $70 \%$ of their respective $\mathrm{VO}_{2 \max }$ for $60 \mathrm{~min}$. Before the commencement of the run, participants were fitted with heart rate monitor. Blood sample was collected, resting heart rate, tympanic temperature and expired air were measured prior to the warm-up of Run-1. Then, the participants warmed up for $5 \mathrm{~min}$ by running at $50 \%$ of their respective $\mathrm{VO}_{2 \max }$. Blood sample was collected at the end of warm up. After the warmup, the intensity was increased to $70 \%$ of their respective $\mathrm{VO}_{2 \max }$. At intervals of 20 min during Run-1, expired air samples, heart rate, tympanic temperature, room temperature and relative humidity were recorded. At the end of the $60 \mathrm{~min}$ run, blood sample was collected and expired air, heart rate and tympanic temperature were recorded. Then, post-exercise nude body weight was obtained after the participant had towel-dried themselves.

\section{REHYDRATION PHASE}

After completion of Run-1, the participants were required to rest for $2 \mathrm{~h}$. During this rehydration phase, plain water or honey drink or sports drink was consumed by the participants in a randomized fashion (counterbalanced). The amount of fluid which was ingested by the participants was equivalent to $150 \%$ of body weight loss (Lee et al. 2011; Maughan et al. 1996) in 3 boluses of $60 \%, 50 \%$, and $40 \%$ consecutively (Ahmad et al. 2020; Saat et al. 2002). Ingestion of the drink was at 0,30 , and 60 min during the rehydration phase. Blood and urine samples were also taken at every $30 \mathrm{~min}$ during this period.

\section{MIN SELF-PACED TIME TRIAL PERFORMANCE (RUN-2)}

The participants were then required to perform a 20 min self-paced running time trial (Run-2), where the longest distance covered in $20 \mathrm{~min}$ was used to indicate endurance running performance. Other studies have also used self-paced time trial to determine exercise performance (Bradbury et al. 2019; Holgado et al. 2019; McGawley 2017; Ping et al. 2018). The speed of running during the time trial was self-paced by the participants via a speed controller. Blood sample, expired air, heart rate, tympanic temperature, and RPE were taken at the end of the time trial. Urine sample was also collected after completing the time trial. Then, post-exercise nude body weight was obtained after participants has toweldried themselves.

\section{BLOOD ANALYSIS}

Eight $\mathrm{mL}$ of blood was collected during each blood withdrawal. One $\mathrm{mL}$ of the blood was transferred into an EDTA (Ethylenediamine tetra-acetic acid) tube. It was used to measure the hematocrit levels using the capillary method via a micro hematocrit reader (Hawksley, England). The plasma volume changes were calculated from the results of these hematocrit levels using the formula of van Beaumont et al. (1981). The rest of the blood was transferred into another tube containing natrium fluoride as the anticoagulant. After centrifugation at $3000 \mathrm{rpm}$ for $10 \mathrm{~min}$ at $4{ }^{\circ} \mathrm{C}$, the plasma was transferred into a $1.5 \mathrm{~mL}$ tube and stored at $-40{ }^{\circ} \mathrm{C}$ for subsequent analysis of glucose, cortisol, insulin, and free fatty acid. Plasma glucose concentration was determined by the enzymatic oxidation method (Randox, United Kingdom) while insulin concentrations were determined using a spectrophotometer (Spekol 200, Germany). Plasma cortisol levels were measured using an ELISA kit (Human, Germany) while plasma free fatty acid concentrations were determined by acylcoenzyme-A-synthetase (ACS) and acyl-coenzyme-A-oxidase (ACOD) method (Wako, Japan). Intra-assay coefficients of variation $(\mathrm{CV})$ for glucose, cortisol, insulin and free fatty acid were 5.7, 5.2, 2.9, and $7.9 \%$, respectively.

\section{URINE ANALYSIS}

Urine volume was measured using a measuring cylinder, and urine osmolality was measured by using cryscopic osmometer (Osmomat 030, Gonotec, Germany). Urine specific gravity was measured using a refractometer 
(Atago, SPR-T2, Japan). These parameters were measured to indicate the participants' rehydration status during the rehydration phase.

\section{STATISTICAL ANALYSIS}

Changes in physiological responses, hematological, and urine parameters were analyzed using a two-way ANOVA with repeated measures. When appropriate, Bonferroni post hoc analyses were used to examine differences between trials. The $20 \mathrm{~min}$ self-paced time trial performance with all three drinks were analyzed using one-way ANOVA. The Statistical Package for Social Sciences (SPSS) program version 22.0 was used for statistical analysis. Differences were considered significant at $\mathrm{p}<0.05$. Results are presented as means $\pm \mathrm{SD}$.

\section{RESULTS}

\section{PARTICIPANT'S PHYSIOLOGICAL CHARACTERISTICS}

Ten healthy male recreational runners completed this study. Their age, body weight, height, body mass index, and $\mathrm{VO}_{2 \max }$ are $22.2 \pm 1.7$ years, $65.7 \pm 5.3 \mathrm{~kg}$., $170.4 \pm$ $3.5 \mathrm{~cm}, 22.7 \pm 1.6 \mathrm{~kg} \cdot \mathrm{m}^{-2}$ and $51.5 \pm 3.7 \mathrm{~mL} \cdot \mathrm{kg}^{-1} \cdot \mathrm{min}^{-1}$, respectively. In all the three trials, room temperature and relative humidity were well-maintained at $31.4{ }^{\circ} \mathrm{C}$ and $70.4 \%$, respectively (Table 1 ).

TABLE 1. Room temperature, relative humidity, body weight changes in plain water (W), honey (H) and sports drink (SPD) trials during Run-1 and Run-2

\begin{tabular}{lllc}
\hline Variables & W trial & H trial & SPD trial \\
\hline Room temperature $\left({ }^{\circ} \mathrm{C}\right)$ & $31.4 \pm 0.2$ & $31.4 \pm 0.2$ & $31.4 \pm 0.1$ \\
Relative humidity $(\%)$ & $70.4 \pm 0.1$ & $70.4 \pm 0.2$ & $70.4 \pm 0.2$ \\
Pre Run-1 body weight $(\mathrm{kg})$ & $65.7 \pm 5.0$ & $65.5 \pm 4.7$ & $65.5 \pm 5.1$ \\
Post Run-1 body weight (kg) & $64.4 \pm 4.8$ & $64.1 \pm 4.6$ & $64.1 \pm 5.0$ \\
Body weight changes after Run-1 (\%) & $2.0 \pm 0.4$ & $2.1 \pm 0.3$ & $2.1 \pm 0.3$ \\
Pre Run-2 body weight (kg) & $65.4 \pm 5.0$ & $65.3 \pm 4.7$ & $65.3 \pm 5.3$ \\
Post Run-2 body weight (kg) & $64.8 \pm 4.3$ & $64.7 \pm 4.6$ & $64.6 \pm 5.2$ \\
Body weight changes after Run-2 (\%) & $1.0 \pm 0.3$ & $1.0 \pm 0.2$ & $1.0 \pm 0.4$ \\
\hline
\end{tabular}

Body weight of the participants at Pre-Run-1 and Post Run-1 were not significantly different among the three trials (Table 1). Percent body weight loss after Run 1 was $2.0 \%$ or more and it was not different among the three trials. Similarly, body weight of the participants at Pre Run-2 and Post Run-2 was not different among the three trials. After Run 2, the percent body weight changes in all the three trials was $1.0 \%$. The total volume of fluid consumed during the rehydration phase in the water, honey and sports drink trials was $2010 \pm 395.0 \mathrm{~mL}, 2055$ $\pm 367.8 \mathrm{~mL}$ and $2055 \pm 332.0 \mathrm{~mL}$, respectively. These amounts of fluid were equivalent to $150 \%$ of body weight loss in the respective trials and they were not significantly different among the three trials.

\section{MIN SELF-PACED TIME TRIAL PERFORMANCE}

The participants ran a significantly $(p<0.05)$ longer distance of $249 \mathrm{~m}$ in the honey $(\mathrm{H})$ trial compared to water (W) trial. However, there was no statistical difference in the distance ran between $\mathrm{H}$ and sports drink (SPD) trials. Similarly, there was no statistical difference in the distance ran between SPD and W trials. The mean distance ran in the time trial performance in $\mathrm{W}, \mathrm{H}$, and SPD trials was $3019 \pm 246.3 \mathrm{~m}, 3268 \pm 215.9 \mathrm{~m}$, and 3230 $\pm 263.8 \mathrm{~m}$, respectively (Figure 1). 


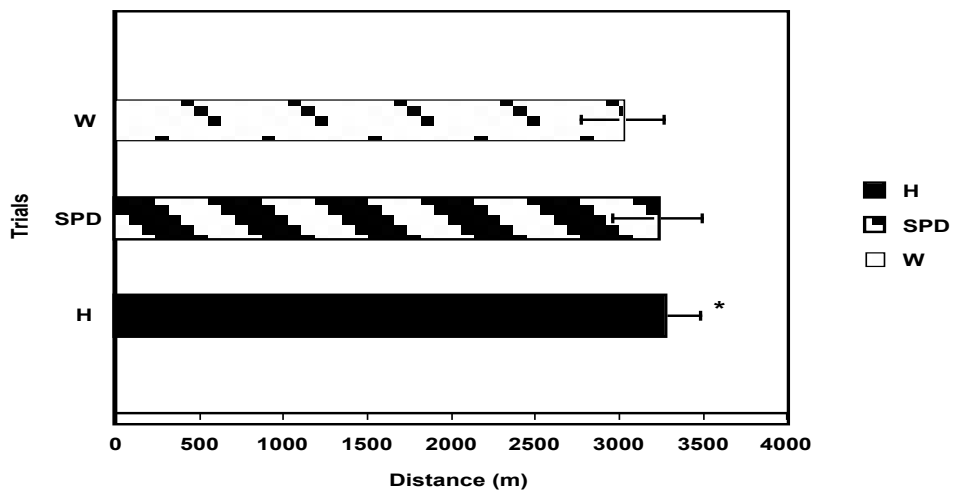

FIGURE 1. Endurance running time trial performance of plain water $(\mathrm{W})$, honey $(\mathrm{H})$ and sports drink (SPD) trials. *denotes

significantly different from $\mathrm{W}$ trial at $p<0.05$

\section{OXYGEN CONSUMPTION AND TYMPANIC TEMPERATURE}

There was a significant main effect of time $(\mathrm{F}=602.14$; $\mathrm{p}<0.05)$ on oxygen uptake. However, there was no significant interaction between time and trial $(\mathrm{F}=0.75$; $\mathrm{p}=0.720$ ) on oxygen uptake. In all the three trials, oxygen uptake significantly $(\mathrm{p}<0.001)$ increased over time during Run-1 and time trial performance. However, there were no significant differences in oxygen uptake at any time points between W, H, and SPD trials (Figure 2(A)). Tympanic temperature did not show any significant differences at any time points among the three trials. In $\mathrm{W}, \mathrm{H}$, and SPD trials, tympanic temperature was significantly higher at the end of Run-1 compared to the resting values and at the end of Run- 2 compared to the pre-run values (Figure 2(B)).

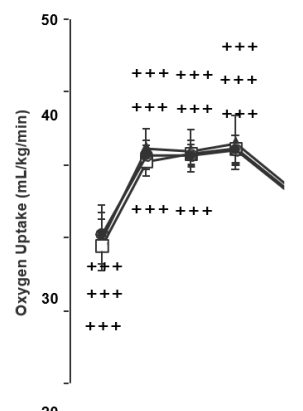

20

III

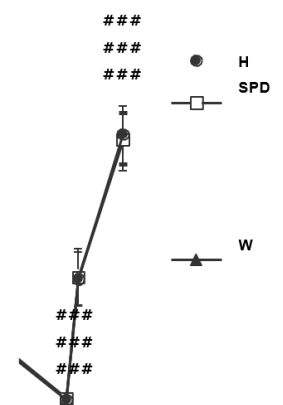

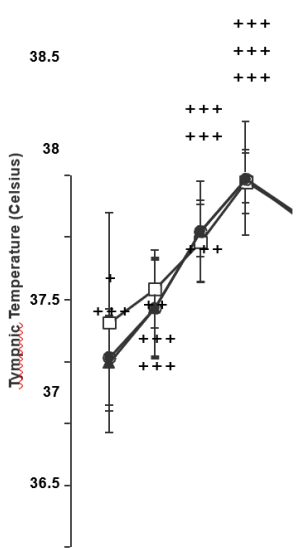

III

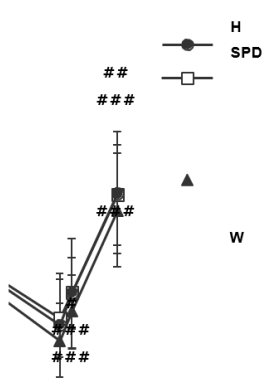

36

35.5

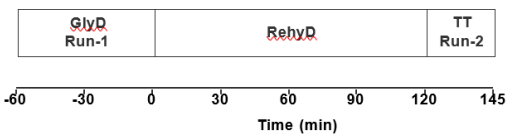

Tympanic temperature during Run-1 and Run-2 (B)

Oxygen uptake during Run-1 and Run-2 (A)

FIGURE 2. Oxygen uptake during Run-1 and Run-2 (A) and tympanic temperature during Run-1 and Run-2 (B) of plain water $(\mathrm{W})$, honey $(\mathrm{H})$ and sports drink (SPD) trials. *denotes significantly different from $\mathrm{W}$ trial at $p<0.05,+++$ denotes significantly different from respective resting value of Run- 1 at $p<0.001$, \#\#\# denotes significantly different from respective end of rehydration phase at $p<0.001$. GlyD $=$ Pre-load phase; RehyD $=$ rehydration phase; $\mathrm{TT}=$ Time Trial 
HEART RATE RESPONSE AND RATINGS OF PERCEIVED EXERTION

There was a significant main effect of time on heart rate during $\mathrm{W}, \mathrm{H}$, and $\mathrm{SPD}$ trials $(\mathrm{F}=245.52 ; \mathrm{p}<0.001)$. However, there were no significant interaction between time and trial on heart rate $(F=1.017 ; p=0.441)$. Heart rate increased significantly over time in all the three trials during Run-1 and Run-2 $(\mathrm{p}<0.001)$. However, there were no significant differences in heart rate at any time points between W, H, and SPD trials (Figure 3(A)). There was a significant main effect of time on RPE during W, $\mathrm{H}$, and SPD trials $(\mathrm{F}=151.36 ; \mathrm{p}<0.05)$. However, there were no significant interaction between time and trial on RPE $(F=1.18 ; p=0.317)$. Rate of perceived exertion (RPE) significantly increased over time in all the three trials (Figure 3(B)). However, there were no significant differences in RPE at any time points between $\mathrm{W}, \mathrm{H}$, and SPD trials.
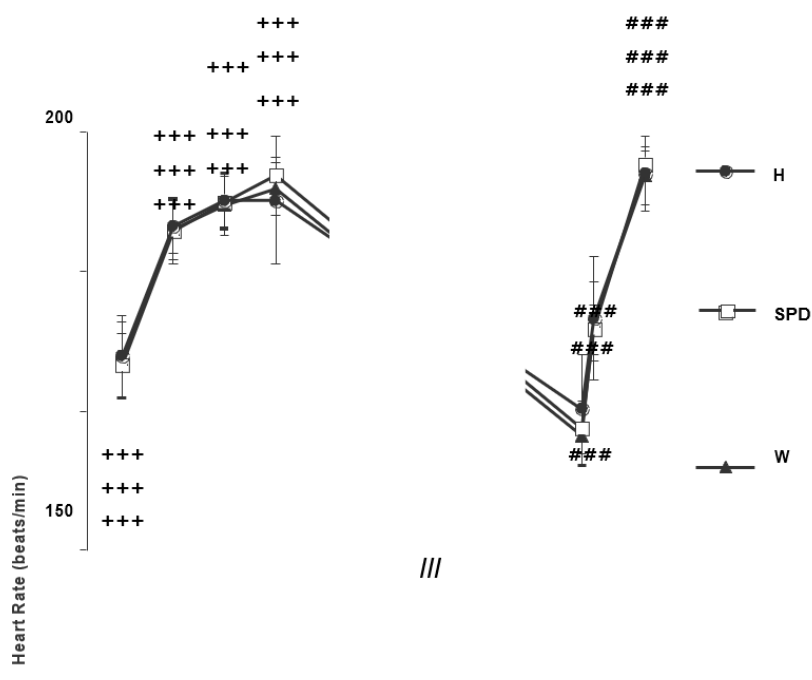

III

100

50

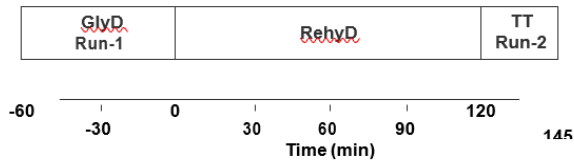

Heart rate during Run-1 and Run-2 (A)

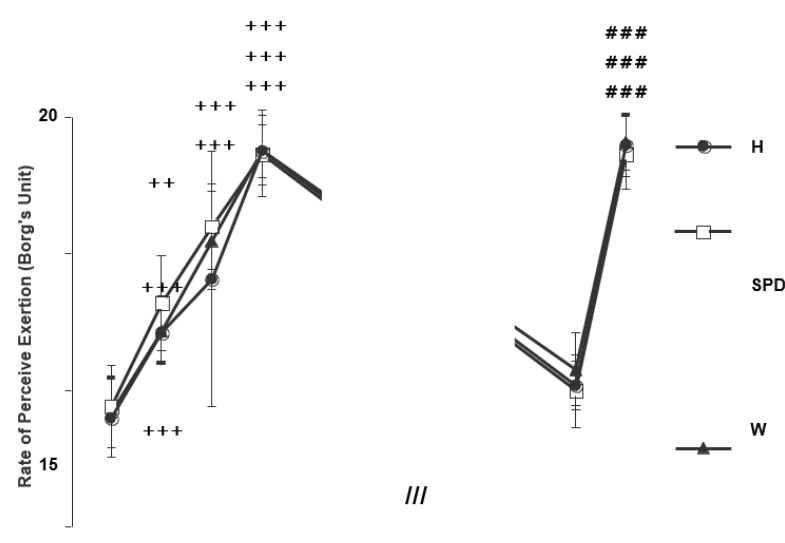

10

5

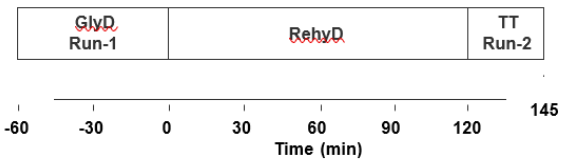

Rate of perceived exertion during Run-1 and Run-2 (B)

FIGURE 3. Heart rate during Run-1 and Run-2 (A) and rate of perceived exertion during Run-1 and Run-2 (B) of plain water $(\mathrm{W})$, honey $(\mathrm{H})$ and sports drink $(\mathrm{SPD})$ trials.,,++++++ denotes significantly different from respective resting value of Run-1 at $p<0.05, p<0.01$ and $p<0.001$ respectively. \#, \#\#, \#\# denotes significantly different from respective end of rehydration phase at $p<0.05, p<0.01$ and $p<0.001$. GlyD $=$ Pre-load phase; 


\section{PLASMA VOLUME CHANGES}

A significant main effect of time on plasma volume changes (PVC) was observed in $\mathrm{W}, \mathrm{H}$, and SPD trials $(\mathrm{F}=132.90 ; \mathrm{p}<0.001)$. There was a significant interaction between time and trial on PVC at any time point between all trials $(\mathrm{F}=3.011 ; \mathrm{p}<0.05)$. Plasma volume decreased significantly $(\mathrm{p}<0.05)$ during Run-1 in all three trials (Figure 4(A)). After $30 \mathrm{~min}$ in the rehydration phase, there was a significant decrease $(\mathrm{p}<0.05)$ of plasma volume during Run-1 in all three trials. During the rehydration phase, there was a significant increase $(p<0.05)$ of plasma volume in all three trials. The plasma volume was maintained throughout the $2 \mathrm{~h}$ rehydration phase. During Run-2, plasma volume decreased significantly $(p<0.05)$ until the end of 20 min time trial performance for all three trials (Figure 4(A)).

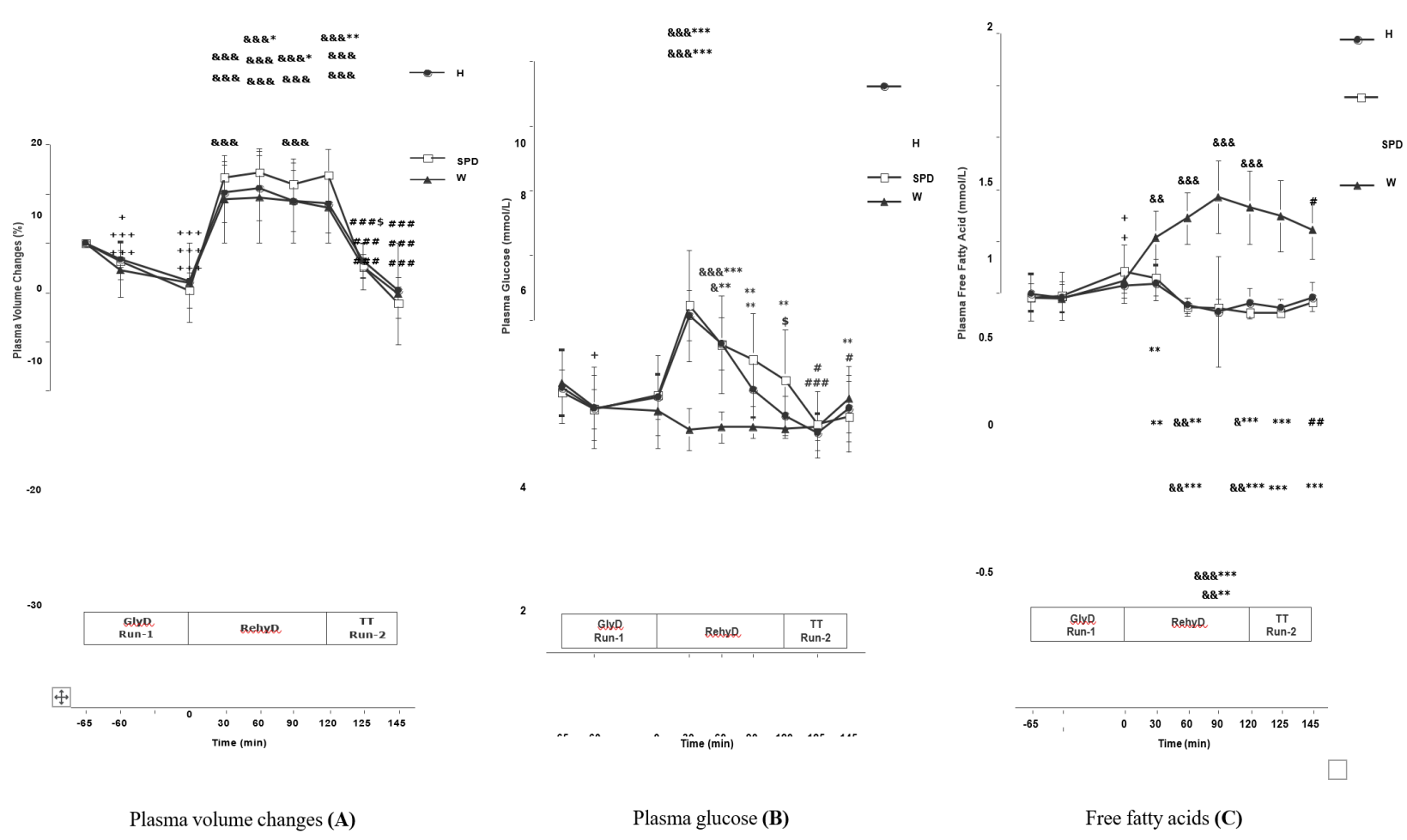

FIGURE 4. Plasma volume changes (A), plasma glucose (B), and free fatty acids (C) concentrations of plain water $(\mathrm{W})$, honey $(\mathrm{H})$ and sports drink (SPD) trials.,,++++++ denotes significantly different from respective resting value of Run- 1 at $p<0.05, p<0.01$ and $p<0.001$, respectively. $\&, \& \&, \& \& \&$ denotes significantly different from respective end of Run- 1 at $\mathrm{p}<0.05, \mathrm{p}<0.01$ and $\mathrm{p}<0.001$ respectively. \#, \#\#, \#\#\# denotes significantly different from respective end of rehydration phase at $p<0.05, p<0.01$ and $p<0.001$.

$*, * *, * * *$ denotes significantly different from corresponding value of $\mathrm{W}$ trial at $\mathrm{p}<0.05, \mathrm{p}<0.01$ and $\mathrm{p}<0.01$ respectively. $\$$ denotes significantly different from corresponding value in $\mathrm{H}$ trial at $\mathrm{p}<0.05$. GlyD $=$ Pre-load phase; RehyD = rehydration phase; TT= Time Trial 


\section{PLASMA GLUCOSE}

There was significant main effect of time on plasma glucose concentration in all three trials $(\mathrm{F}=13.67 ; \mathrm{p}<0.001)$. There was also a significant interaction between time and trial on plasma glucose concentration at any time point in $\mathrm{W}, \mathrm{H}$, and SPD trials $(\mathrm{F}=12.43 ; \mathrm{p}<0.001)$. In all three trials, plasma glucose concentration showed a decreased trend during $60 \mathrm{~min}$ of running (Figure 4(B)). In the rehydration phase, plasma glucose increased significantly $(\mathrm{p}<0.05)$ during the first 30 min of rehydration in both $\mathrm{H}$ and SPD trials. At 30th, 60 th, and 90th min of rehydration, plasma glucose concentration was significantly $(p<0.05)$ higher in $\mathrm{H}$ and SPD trials compared to $\mathrm{W}$ trial. During 120 min of rehydration, it was observed that there was a significantly higher plasma glucose concentration in SPD trial compared to $\mathrm{H}$ trial (Figure 4(B)).

\section{PLASMA FREE FATTY ACID}

There was a significant main effect of time on plasma free fatty acid (FFA) in $\mathrm{W}, \mathrm{H}$, and SPD trials $(\mathrm{F}=8.94 ; \mathrm{p}<0.05)$. There was also a significant interaction between time and trial on FFA at any time point of all trials $(\mathrm{F}=29.16$; $\mathrm{p}<0.001$ ). During Run-1, there was a trend of increased plasma free fatty acid albeit the absence of statistical significance (Figure 4(C)). During the rehydration phase, there was a decreased trend in both $\mathrm{H}$ and SPD trials with a significance $(\mathrm{p}<0.05)$ difference compared to $\mathrm{W}$ trial from 90th min. At 120th min of rehydration phase, there was a significant $(p<0.05)$ decrease in plasma free fatty acid compared to its respective resting value in the $\mathrm{W}$ trial. At $120 \mathrm{~min}$ of rehydration phase, plasma free fatty acid started to decrease with a significant $(\mathrm{p}<0.05)$ value for $\mathrm{H}$ and SPD trials when compared to their respective resting values. Towards the end of time trial, plasma free fatty acid in the $\mathrm{W}$ trial continued to decrease over time with no significant difference compared to end of Run-1. For both H and SPD trials, there was a significant $(p<0.05)$ increase in plasma free fatty acid compared to end of rehydration phase.

\section{PLASMA INSULIN}

There was a significant main effect of time on plasma insulin concentration in $\mathrm{W}, \mathrm{H}$, and $\mathrm{SPD}(\mathrm{F}=25.64$;

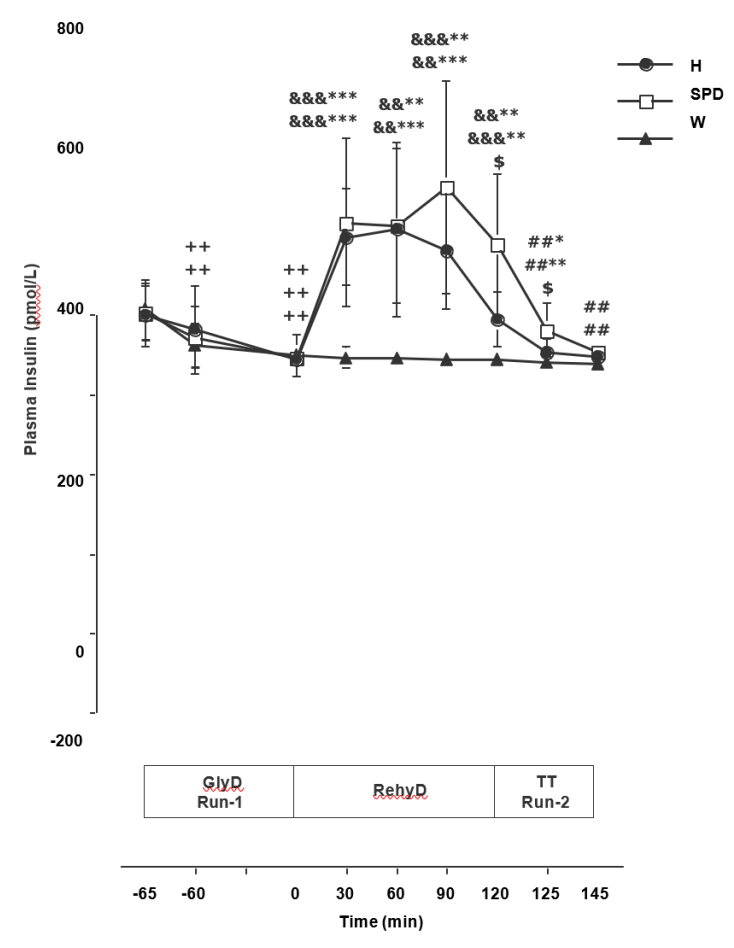

Insulin (A)

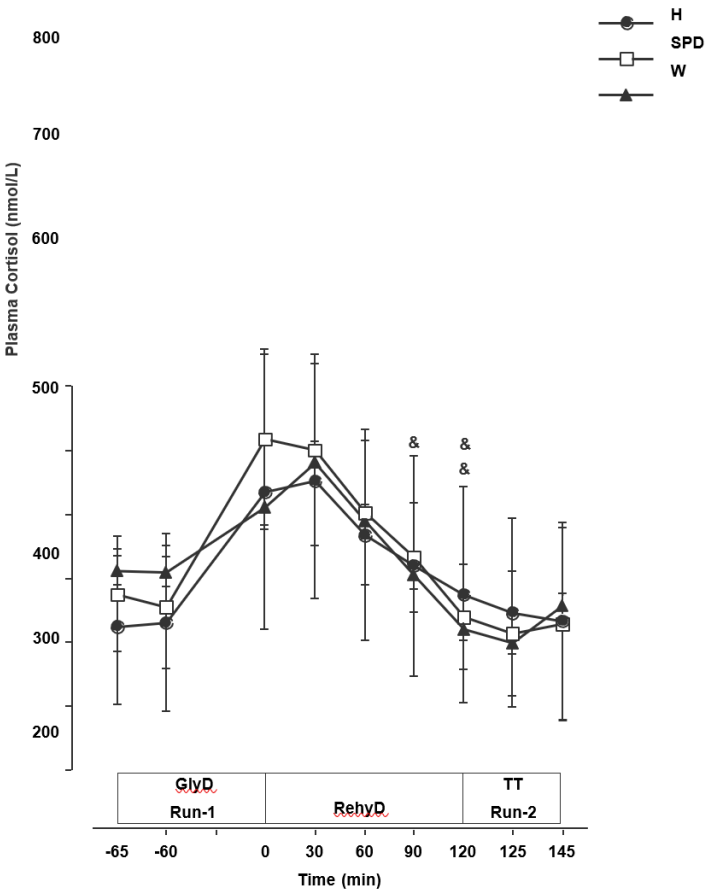

Cortisol (B)

FIGURE 5. Insulin (A) and cortisol (B) concentrations of plain water (W), honey (H) and sports drink (SPD) trials.,,++++++ denotes significantly different from respective resting value of Run-1 at $p<0.05, p<0.01$ and $p<0.001$ respectively. $\boldsymbol{\&}, \boldsymbol{\&} \boldsymbol{\&}, \boldsymbol{\&} \boldsymbol{\&} \boldsymbol{\&}$ denotes significantly different from respective end of Run-1 at $\mathrm{p}<0.05, \mathrm{p}<0.01$ and $\mathrm{p}<0.001$ respectively. \#, \#\#, \#\# denotes significantly different from respective end of rehydration phase at $p<0.05, p<0.01$ and $p<0.001 . *, * *, * * *$ denotes significantly different from corresponding value of $\mathrm{W}$ trial at $\mathrm{p}<0.05, \mathrm{p}<0.01$ and $\mathrm{p}<0.01$ respectively. $\$$ denotes significantly different from corresponding value in $\mathrm{H}$ trial at $\mathrm{p}<0.05$. GlyD; = Pre-load phase; RehyD = rehydration phase; 
$\mathrm{p}<0.001)$. There was also a significant interaction between time and trial on plasma insulin concentration at any time point of $\mathrm{W}, \mathrm{H}$, and SPD trials $(\mathrm{F}=9.37$; $\mathrm{p}<0.001)$. Plasma insulin concentration significantly $(\mathrm{p}<0.05)$ decreased at the end of Run-1 compared to the respective resting values during Run-1 (Figure 5(A)). After $30 \mathrm{~min}$ in the rehydration phase, plasma insulin concentration significantly increased $(\mathrm{p}<0.05)$ for both $\mathrm{H}$ and SPD trials. Plasma insulin concentration continued to increase significantly $(p<0.05)$ after 60 and 90 min of rehydration phase for SPD trial compared to its resting value and when compared to $\mathrm{W}$ trial. In $\mathrm{H}$ trial, at $60 \mathrm{~min}$ in the rehydration phase, plasma insulin was also significantly $(\mathrm{p}<0.05)$ higher compared to $\mathrm{W}$ trial. Towards the end of rehydration phase, plasma insulin concentration continued to decrease significantly in both $\mathrm{H}$ and SPD trials. During Run-2, it was observed that plasma insulin concentration significantly decreased $(p<0.05)$ compared to their respective pre-Run 2 values in both $\mathrm{H}$ and SPD trials (Figure 5(A)).

\section{PLASMA CORTISOL}

There was a significant main effect of time on plasma cortisol concentration $(\mathrm{F}=17.08 ; \mathrm{p}<0.05)$ in $\mathrm{W}, \mathrm{H}$, and SPD trials. However, there was no significant interaction between time and trial at any time point of plasma cortisol in all three trials $(\mathrm{F}=1.15 ; \mathrm{p}=0.311)$. In Run-1, plasma cortisol exhibited an initial increased trend in all three trials (Figure 5(B)). However, plasma cortisol declined gradually in all three trials from $30 \mathrm{~min}$ in the rehydration phase with a significant value $(p<0.05)$ at $90 \mathrm{~min}$ in the SPD trial and at $120 \mathrm{~min}$ for both $\mathrm{W}$ and SPD trials compared to their corresponding values at the beginning of the rehydration phase. Towards the end of Run-2, plasma cortisol started to increase until the end of the trial although statistical significance was not observed (Figure 5(B)).

\section{URINE VOLUME, OSMOLALITY, AND SPECIFIC GRAVITY}

There was a significant main effect of time on total urine volume during the trials $(\mathrm{F}=48.26 ; \mathrm{p}<0.05)$. However, there was no significant interaction between time and trial at any time point between all trials $(\mathrm{F}=0.78 ; \mathrm{p}=0.67)$. During the rehydration phase, urine volume decreased significantly $(\mathrm{p}<0.05)$ compared to respective resting values in $\mathrm{W}, \mathrm{H}$, and SPD trials (Figure 6(A)). Towards the end of the rehydration phase, urine volume showed an increased trend with a statistical significance $(\mathrm{p}<0.05)$ at the end of rehydration phase in $\mathrm{W}$ and $\mathrm{H}$ trials. At the end of Run-2, there was a significant decrease of urine volume in $\mathrm{W}$ and $\mathrm{H}$ trials compared to end of rehydration phase. However, there were no significant differences in urine volume between all three trials, at any time point.

There was a significant main effect of time on urine osmolality during trials $(\mathrm{F}=48.23 ; \mathrm{p}<0.001)$. However, there was no significant interaction between time and

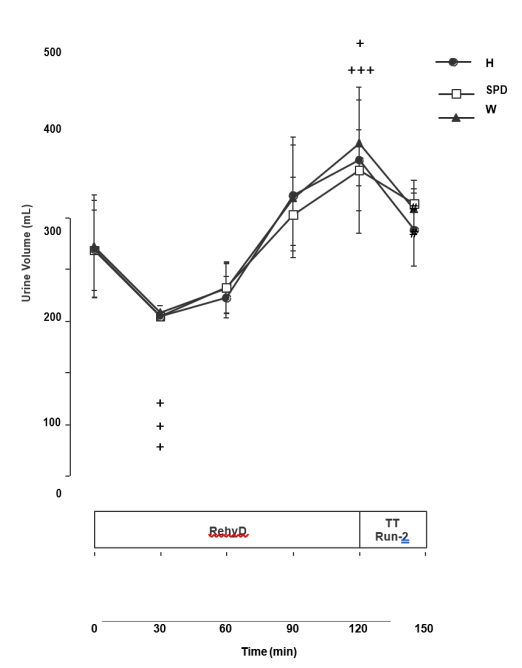

Urine volume (A)
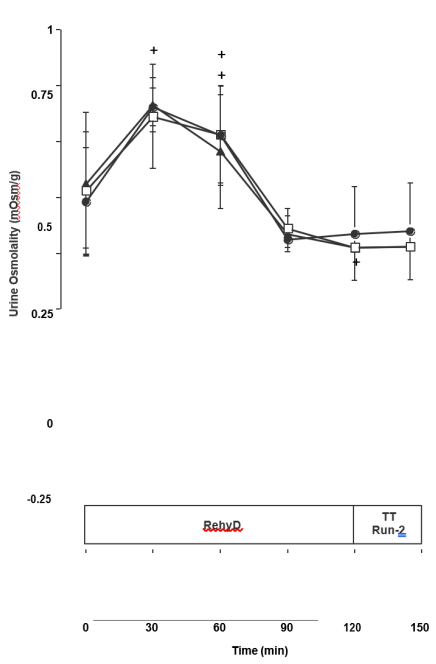

Urine osmolality (B)

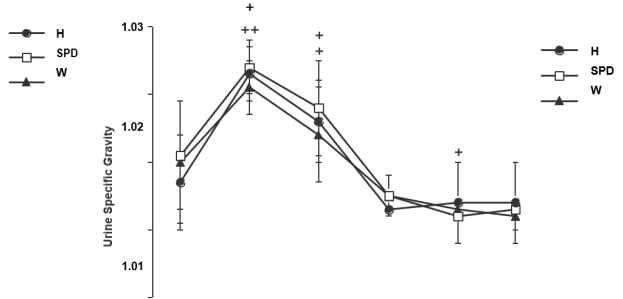

1

0.99

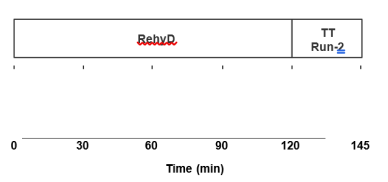

Urine specific gravity (C)

FIGURE 6. Urine volume (A), osmolality (B), and specific gravity (C) of plain water (W), honey (H) and sports drink (SPD) trials.,,++++++ denotes significantly different from respective resting value of Run-1 at $p<0.05, p<0.01$ and $p<0.001$ respectively. \# denotes significantly different from respective end of rehydration phase at $p<0.05$. GlyD $=$ Pre-load phase; RehyD $=$ rehydration phase; TT= Time Trial 
trial on urine osmolality $(\mathrm{F}=0.77 ; \mathrm{p}=0.68)$. During the first $30 \mathrm{~min}$ of rehydration, all three trials showed an increased trend in urine osmolality, but statistical significance $(\mathrm{p}<0.05)$ was only observed in $\mathrm{H}$ trial (Figure $6(\mathrm{~B})$ ). Towards the end of rehydration phase, urine osmolality started to show a decreased pattern. After $60 \mathrm{~min}$ of rehydration, there was a significant $(\mathrm{p}<0.05)$ decrease in urine osmolality for both $\mathrm{H}$ and SPD trials. At the end of rehydration phase, $\mathrm{H}$ trial showed a significant $(\mathrm{p}<0.05)$ difference in urine osmolality compared to the start of the rehydration phase.

There was a significant main effect of time on urine specific gravity (SG) of $\mathrm{W}, \mathrm{H}$, and $\mathrm{SPD}$ trials $(\mathrm{F}=59.30$; $\mathrm{p}<0.001)$. However, there was no significant interaction between time and trial at any time point of all three trials $(\mathrm{F}=1.53 ; \mathrm{p}=0.11)$. There was significant $(\mathrm{p}<0.05)$ increase in urine specific gravity for the first $30 \mathrm{~min}$ compared to resting values for both $\mathrm{H}$ and SPD trials (Figure 6(C)). Towards the end of rehydration phase, there was a trend of a significant decrease in urine specific gravity with a significant $(\mathrm{p}<0.05)$ value for $\mathrm{H}$ and SPD trials at 60 th and 120th min during the rehydration phase. During Run2 , there were no significant differences in urine specific gravity in all three trials compared to the respective values at the beginning of Run-2.

\section{DISCUSSION}

The most notable finding in the present study was that Acacia honey drink elicited a significant improved self-paced time trial (TT) performance compared to the water trial. However, TT performance was not different between SPD trial and the other two trials. A previous study by Ahmad et al. (2015) has also shown similar result on the effectiveness of Acacia honey drink on running performance. They demonstrated that participants who ingested honey ran a longer distance of $300 \mathrm{~m}$ compared to the water trial although this was not statistically significant. The finding of this study was also consistent with the findings of Earnest et al. (2004) where cyclists who ingested gel containing flavored honey, with 250 $\mathrm{mL}$ of water at every $16 \mathrm{~km}$ for $64 \mathrm{~km}$ finished the time trial much faster compared to the placebo (artificially flavored gel) trial. It is speculated that the improved performance with Acacia honey drink could be attributed to the higher caloric content compared to the other two drinks. In addition, honey drink consists various types of carbohydrates compared with the sports drink. It has been previously reported that a mixture of multiple carbohydrates elicited a higher level of carbohydrate oxidation during exercise, presumably through different absorptive pathways for each type of carbohydrate consumed (Jentjens et al. 2004).

The other possible contributory factor for the significant improvement in endurance performance in the honey trial was the protein content in the honey drink. Several studies have reported significant improved endurance performance when protein was co-ingested with carbohydrate during prolonged exercise (Ivy et al. 2003; Saunders et al. 2007, 2004). Compared with carbohydrates and fats, protein provides a relatively small contribution to the total energy demands during endurance events (Dohm 1986). However, this proportion may increase when exercise is performed in a glycogen-depleted condition such as during the late stages of an endurance run (Lemon 1998). Thus, it is speculated that carbohydrate and protein ingestion during prolonged exercise may increase protein oxidation and subsequently alter substrate utilization and potentially spare muscle glycogen at the end stage of prolonged exercise (Saunders 2007).

The plasma volume reduced significantly immediately during all three trials after exercise when compared to their respective resting values in Run-1. This significant reduction of plasma volume implied that the participants were dehydrated after completing Run-1. Plasma volume was significantly higher following the rehydration phase. The increased level of plasma volume indicated that the participants were successfully rehydrated to balance the fluid loss following Run-1. The increase in plasma volume during the recovery period were also observed in previous studies (Ahmad et al. 2015; Wilmore et al. 2008). Fluid loss occurs among body fluid compartments, between plasma, extracellular, and intracellular waters. The water loss causes fluid mobilization from the intercellular water to maintain the extracellular water volume. Thus, to prevent inadequate blood flow to muscles during prolonged exercise, dehydration should be avoided (Gonzalez-Alonso et al. 1992).

The present study showed that water and honey trials elicited similar effect in restoring plasma volume after exercise-induced dehydration. A recent study using yogurt has also been found to prevent dehydrationinduced changes in the blood and osmolality was maintained within the normal range after exercise (Niksefat et al. 2019). The higher plasma volume of sports drink during rehydration period observed in the present study may be due to electrolyte contained in the sports drink. This 
is based on the phenomenon that drinks with electrolyte solution can elicit higher plasma volume when compared to plain water without electrolyte (Singh 2003).

Blood glucose concentration was not different at the start of the three experimental trials. However, blood glucose levels were significantly higher in both honey and sports drink trials compared to the water trial after $30 \mathrm{~min}$ in the rehydration phase and at the end of time trial. It was observed that throughout the rehydration phase, sports drink seems to better maintain plasma glucose compared to the honey trial. However, this phenomenon did not contribute to a better running performance compared to honey drink. This precise mechanism is unclear and further studies are warranted. Collectively, the present observation indicated that honey and sports drink could increase plasma glucose during the rehydration phase but not the water trial. The ingestion of carbohydrate during rapid rehydration is advantageous because glycogen re-synthesis is doubled if carbohydrate is ingested immediately after exercise. In addition, fructose contained in the honey is beneficial for the replenishment of liver glycogen (Ivy 1999). Consumption of fructose or sucrose present in honey during the recovery period has been shown to increase the supply of glycogen substrate, thus, increases the restoration of endogenous glycogen stores, including the liver (Bowtell et al. 2000; Gonzalez et al. 2017).

One of the responses to endurance performance is a decrease in carbohydrate utilization and an increased fatty acids oxidation during exercise (Sidossis et al. 1998). In the present study, significant differences in free fatty acid between trials were observed after 30 min of rehydration phase in the honey and sports drink compared to the water trial. After $30 \mathrm{~min}$ of rehydration, honey and sports drink trials elicited significant reduction of plasma free fatty acids towards the end of rehydration phase compared to the water trial. Plasma free fatty acids for water trial was higher compared to honey and sports drink trials throughout rehydration period.

This finding of increased plasma free fatty acid in the water trial is consistent with observations of increased plasma free fatty acid concentrations during immediate postexercise recovery reported in other studies (Bahr et al. 1991; Hagenfeldt \& Wahren 1975; Lundsgaard et al. 2020; Magkos et al. 2009). The observed postexercise peak in plasma free fatty acid is probably due to an imbalance between free fatty acid release and uptake after the cessation of exercise, where the utilization of free fatty acid is greatly reduced, whilst lipolysis is maintained
(Hagenfeldt \& Wahren 1975; Lundsgaard et al. 2020; Randle et al. 1963; Wigernaes et al. 2000). The significantly lower plasma free fatty acid in the honey and sports drink trials was attributed to the higher carbohydrate content in both these trials which elicited increased insulin levels during the rehydration phase. Insulin has an antilipolytic action (Randle et al. 1963) and consequently resulted in a lower release of plasma free fatty acid (Wigernaes et al. 2000). Furthermore, there was a significant increase in plasma free fatty acid in sports drinks trial and a significant decreased of plasma free fatty acids in the water trial in Run-2. During endurance performance, there is an increased utilization of lipid as an energetic substrate to the working skeletal muscle (Williams et al. 2003). Thus, the trend of increased plasma free fatty acid during Run-1 and Run-2 may be due to increased cortisol level in the blood stream leading to accelerated mobilization and oxidation of plasma free fatty acids during prolonged exercise (Wilmore et al. 2008). During prolonged exercise with low to moderate intensity, most of the fatty acids oxidized are derived from plasma free fatty acids (Horowitz \& Klein 2000; Matzinger et al. 2002; Van Aggel-Leijssen et al. 2002).

In the present study, changes in plasma insulin over time in all three trials exhibited similar trend with plasma glucose. These observations indicated that plasma insulin response was correlated with plasma glucose level. Insulin regulates blood glucose level and thus, elevated blood glucose causes insulin to be released which results in glucose entry into cells (McArdle et al. 2010). Plasma insulin in honey and sports drink trials were significantly increased after $30 \mathrm{~min}$ during the rehydration phase. This was probably due to the increase in plasma glucose following the ingestion of honey and sports drink which contain carbohydrate. After the exercise-induced dehydration in Run-1, consuming a drink containing carbohydrates seems to enhance muscle glycogen recovery process by ensuring an adequate supply of carbohydrate to maintain euglycemia (Ivy 1999). Plasma cortisol also increased over time during Run-1. Similar trend was also observed during Run-2 but this increment was not statistically significant. Cortisol exhibits considerable variability depending on exercise intensity and fitness level of the participants, and increased cortisol during exercise could be attributed to its ability to adapt to external changes and stress (Hill et al. 2008; Wilmore et al. 2008). However, when the exercise session ceases, this stress is reduced and leads to the gradual decline in plasma cortisol level as shown in our data during the rehydration period. 
The decline in plasma cortisol at the end of an endurance run or during the recovery period is consistent with the data from other studies (Franca et al. 2006; Tremblay et al. 2004) and it is not affected by plasma glucose level (Farrell et al. 1983).

There was a significant decrease in urine volume after $30 \mathrm{~min}$ of rehydration. Towards the end of the rehydration phase, significant increase in urine volume was observed in the water and honey trials. The increased in urine volume in the SPD trial was also evident towards the end of the rehydration phase but this was not statically significant. This observation of a significantly higher urine volume during recovery when water was consumed compared to a sports drink corroborates with the findings reported in other related studies (Baker \& Jeukendrup 2014; GonzalezAlonso et al. 1992; Lee et al. 2011). However, there was a significant decrease in urine volume at the end of Run2 in the water and honey trials. Urine output increased significantly compared to respective end of Run-1 after fluid ingestion which was equivalent to $150 \%$ of body weight loss. It is consistent with the statement of Maughan and Shirreffs (2004) that urine output after exercise induced dehydration is dependent upon the amount of volume of fluid ingested. Additionally, it has been reported that drink with special formulation in it commonly results in a lower urine output compared to a drink which is not specially formulated (Maughan \& Shirreffs 2004).

Maughan and Shirreffs (2004) also mentioned that urine output is inversely proportional to the sodium content of the ingested fluid. The fluid retention leading to a lower urine output compared to water was due to the presence of sodium in both honey and sports drink. Sodium has been shown to increase renal water reabsorption and thus reduces urine output (Baker \& Jeukendrup 2014; Gonzalez-Alonso et al. 1992; Lee et al. 2011). They concluded that with large amount of fluid ingested, it will not be effective in maintaining positive fluid balance without electrolyte as a tool of restoring fluid deficit. In the absence of electrolyte in the drink, ingesting large amount of fluid will only result in greater amount of urinary output rather than fluid restoration (McArdle et al. 2010). Urine specific gravity $\left(\mathrm{U}_{\mathrm{sg}}\right)$ and urine osmolality $\left(\mathrm{U}_{\mathrm{osm}}\right)$ can serve as an alternative method in observing hydration status (Armstrong et al. 1998). They showed that $U_{\mathrm{sg}}$ and $\mathrm{U}_{\text {osm }}$ were strongly correlated, thus, concluded that these parameters can be used by athletes as a meaningful index of hydration status. In the present study, it was also observed that Uosm, and Usg exhibited a similar trend as shown in
Figure 6. $\mathrm{U}_{\mathrm{sg}}$ and $\mathrm{U}_{\text {osm }}$ increased during the first $30 \mathrm{~min}$ in all three trials. Subsequently, $U_{\text {sg }}$ and $U_{\text {osm }}$ decreased in all three trials towards the end of the rehydration phase. During Run-2, only a slight change was observed at the end of time trial.

$\mathrm{U}_{\mathrm{sg}}$ and $\mathrm{U}_{\mathrm{osm}}$ are determined by solute particle concentration. In the first $30 \mathrm{~min}$ of rehydration phase of this study, $U_{\text {osm }}$ was higher because of higher solute concentration due to the loss of body water in the form of sweat during Run-1. Towards the end of rehydration phase, $U_{\text {osm }}$ returned to euhydration status which indicated that fluid clearance by the kidney lead to the restoration of $U_{\text {osm }}$ to the normal range (Saat et al. 2002). Participants were considered to have achieved their euhydration status based on the observation that $\mathrm{U}_{\mathrm{sg}}$ and $\mathrm{U}_{\mathrm{osm}}$ were lowered below 1.020 and $700 \mathrm{mOsm} . \mathrm{kg}^{-1}$, respectively, during $2 \mathrm{~h}$ of rehydration. $\mathrm{U}_{\mathrm{sg}}$ was lowered to $1.003 \pm$ $0.001,1.004 \pm 0.006$ and $1.002 \pm 0.001$, respectively, in water, honey, and sports drink trials. As for $\mathrm{U}_{\text {osm }}$, it was also lowered to $0.056 \pm 0.013,0.116 \pm 0.210$ and $0.056 \pm$ 0.015 , respectively, in water, honey and sports drink trials. Limitations of the present study include the duration of the self-pace time trial which was $20 \mathrm{~min}$ and non-elite athletes were recruited as participants. Time trial has been commonly used in previous studies as an indicator for endurance performance and it can be based on the time to complete a certain distance or based on the distance ran in a certain time. In the present study, a 20 min self-paced time trial was used, and this duration has also been reported in a previous study (Ping et al. 2018). Recreational athletes were recruited as participants in this study. Hence, the results obtained from the present study may or may not apply to elite athletes competing at the international level.

\section{CONCLUSION}

The present study showed that Acacia honey ingested during rehydration period elicited a subsequent improved time trial performance in the heat. Thus, Acacia honey has potential to be used as an ergogenic aid for rehydration purposes in individuals who train and compete in a hot and humid environment. For future studies, the effects of Acacia honey on actual endurance events such as marathon, triathlon or road cycling races may be warranted since it has a high content of carbohydrates. In addition, studies on the benefits of honey for sportsperson should include female participants and other types of Malaysian honey such as Tualang, Gelam, and Kelulut. 


\section{ACKNOWLEDGEMENTS}

This research work was supported by the Fundamental Research Grant Scheme (FRGS) from the Ministry of Education, Malaysia (Grant Number: 203/PPSP/6171176). We wish to express our special thanks to Mdm. Jamaayah binti Meor Osman, Ms. Nur Hafizah Hamzah, Ms. Norlida binti Azalan, Ms. Parimalah Velo, Ms. Aini Sudin and Ms. Nurul Ain Fathma Abdullah for their technical assistance throughout this study. Last but not least, our sincere gratitude to all the participants who have participated in this study.

\section{REFERENCES}

Adams, J.D., Scott, D.M., Brand, N.A., Suh, H.G., Seal, A.D., McDermott, B.P., Ganio, M.S. \& Kavouras, S.A. 2019. Mild hypohydration impairs cycle ergometry performance in the heat: A blinded study. Scandinavian Journal of Medicine \& Science in Sports 29(5): 686-695.

Ahmad, N.S., Ismail, M.S., Mohamed, M. \& Ooi, F.K. 2020. Blood glucose metabolism, serum, and urine osmolality in response to sodium-enriched Acacia honey drink consumption during rehydration after exercise in hot and humid environment. Journal of Sustainability Science and Management 15(5): 72-83.

Ahmad, N.S., Ooi, F.K., Ismail, M.S. \& Mohamed, M. 2015. Effects of post-exercise honey drink ingestion on blood glucose and subsequent running performance in the heat. Asian Journal of Sports Medicine 6(3): e24044-e24051.

Armstrong, L.E., Soto, J.A.H., Hacker, F.T., Casa, D.J., Kavouras, S.A. \& Maresh, C.M. 1998. Urinary indices during dehydration, exercise, and rehydration. International Journal of Sport Nutrition and Exercise Metabolism 8(4): 345-355.

Bahr, R., Hostmark, A.T., Newsholme, E.A., Gronnerod, O. \& Sejersted, O.M. 1991. Effect of exercise on recovery changes in plasma levels of FFA, glycerol, glucose and catecholamines. Acta Physiologica Scandinavica 143(1): 105-115.

Baker, L.B. \& Jeukendrup, A.E. 2014. The optimal composition of fluid-replacement beverages. Comprehensive Physiology 4(2): 575-620.

Bowtell, J.L., Gelly, K., Jackman, M.L., Patel, A., Simeoni, M. \& Rennie, M.J. 2000. Effect of different carbohydrate drinks on whole body carbohydrate storage after exhaustive exercise. Journal of Applied Physiology 88(5): 1529-1536.

Bradbury, K.E., Coffman, K.E., Mitchell, K.M., Luippold, A.J., Fulco, C.S. \& Kenefick, R.W. 2019. Separate and combined influences of heat and hypobaric hypoxia on selfpaced aerobic exercise performance. Journal of Applied Physiology 127(2): 513-519.
Casa, D.J., Cheuvront, S.N., Galloway, S.D. \& Shirreffs, S.M. 2019. Fluid needs for training, competition, and recovery in track-and-field athletes. International Journal of Sport Nutrition and Exercise Metabolism 29(2): 175-180.

Dohm, G.L. 1986. Protein as a fuel far endurance exercise. Exercise and Sport Sciences Reviews 14(1): 143-174.

Earnest, C.P., Lancaster, S.L., Rasmussen, C.J., Kerksick, C.M., Lucia, A., Greenwood, M.C., Almada, A.L., Cowan, P.A. \& Kreider, R.B. 2004. Low vs. high glycemic index carbohydrate gel ingestion during simulated $64-\mathrm{km}$ cycling time trial performance. The Journal of Strength \& Conditioning Research 18(3): 466-472.

Edvardsen, E., Hem, E. \& Anderssen, S.A. 2014. End criteria for reaching maximal oxygen uptake must be strict and adjusted to sex and age: A cross-sectional study. PLoS ONE 9(1): e85276-e855283.

Farrell, P.A., Garthwaite, T.L. \& Gustafson, A.B. 1983. Plasma adrenocarticatropin and cortisol responses to submaximal and exhaustive exercise. Journal of Applied Physiology: Respiratory, Environmental and Exercise Physiology 55(5): 1441-1444.

Franca, S.C.A., Neto, T.L.B., Agresta, M.C., Lotufo, R.F.M. \& Kater, C.E. 2006. Divergent responses of serum testosterone and cortisol in athlete men after a marathon race. Brazilian Archives of Endocrinology \& Metabology 50(6): 10821087.

Gheldof, N., Wang, X.H. \& Engeseth, N.J. 2002. Identification and quantification of antioxidant components of honeys from various floral sources. Journal of Agricultural and Food Chemistry 50(21): 5870-5877.

Gonzalez, J.T., Fuchs, C.J., Betts, J.A. \& Van Loon, L.J.C. 2017. Glucose plus fructose ingestion for post-exercise recovery - greater than the sum of its parts? Nutrients 9(4): 344-359.

Gonzalez-Alonso, J., Heaps, C.L. \& Coyle, E.F. 1992. Rehydration after exercise with common beverages and water. International Journal of Sports Medicine 13(5): 399-406.

Hagenfeldt, L. \& Wahren, J. 1975. Turnover of free fatty acids during recovery from exercise. Journal of Applied Physiology 39(2): 247-250.

Hill, E.E., Zack, E., Battaglini, C., Viru, M., Viru, A. \& Hackney, A.C. 2008. Exercise and circulating cortisol levels: The intensity threshold effect. Journal of Endocrinological Investigation 31(7): 587-591.

Holgado, D., Zabala, M. \& Sanabria, D. 2019. No evidence of the effect of cognitive load on self-paced cycling performance. PLoS ONE 14(5): e0217825-e0217835.

Horowitz, J.F. \& Klein, S. 2000. Lipid metabolism during endurance exercise. The American Journal of Clinical Nutrition 72(2): 558-563.

Ivy, J.L. 1999. Role of carbohydrate in physical activity. Clinics in Sports Medicine 18(3): 469-484. 
Ivy, J.L., Res, P.T., Sprague, R.C. \& Widzer, M.O. 2003. Effect of a carbohydrate-protein supplement on endurance performance during exercise of varying intensity. International Journal of Sport Nutrition and Exercise Metabolism 13(3): 382-395.

James, L.J., Moss, J., Henry, J., Papadopoulou, C. \& Mears, S.A. 2017. Hypohydration impairs endurance performance: A blinded study. Physiological Reports 5(12): e13315-e13324.

Jentjens, R.L., Venables, M.C. \& Jeukendrup, A.E. 2004. Oxidation of exogenous glucose, sucrose, and maltose during prolonged cycling exercise. Journal of Applied Physiology 96(4): 1285-1291.

Jeukendrup, A.E. 2004. Carbohydrate intake during exercise and performance. Nutrition 20(7-8): 669-677.

Keen, D.A., Constantopoulos, E. \& Konhilas, J.P. 2016. The impact of post-exercise hydration with deep-ocean mineral water on rehydration and exercise performance. Journal of the International Society of Sports Nutrition 13(1): 17-20.

Keong, C.C., Singh, H.J. \& Singh, R. 2006. Effects of palm vitamin $\mathrm{E}$ supplementation on exercise-induced oxidative stress and endurance performance in the heat. Journal of Sports Science and Medicine 5(4): 629-639.

Khalil, M.I., Mahaneem, M., Jamalullail, S.M.S., Alam, N. \& Sulaiman, S.A. 2011. Evaluation of radical scavenging activity and colour intensity of nine Malaysian honeys of different origin. Journal of ApiProduct and ApiMedical Science 3(1): 4-11.

Lee, J.K.W., Nio, A.Q.X., Ang, W.H., Law, L.Y.L. \& Lim, C.L. 2001. Effects of ingesting a sports drink during exercise and recovery on subsequent endurance capacity. European Journal of Sport Science 11(2): 77-86.

Lemon, P.W. 1998. Effects of exercise on dietary protein requirements. International Journal of Sport Nutrition 8(4): 426-447.

Lopez, R. 2012. Exercise and hydration: Individualizing fluid replacement guidelines. Strength and Conditioning Journal 34(4): 49-54.

Lundsgaard, A.M., Fritzen, A.M. \& Kiens, B. 2020. The importance of fatty acids as nutrients during post-exercise recovery. Nutrients 12(2): 280-293.

Magkos, F., Mohammed, B.S., Patterson, B.W. \& Mittendorfer, B. 2009. Free fatty acid kinetics in the late phase of postexercise recovery: Importance of resting fatty acid metabolism and exercise-induced energy deficit. Metabolism 58(9): 1248 1255 .

Martos, I., Ferreres, F. \& Tomás-Barberán, F.A. 2000. Identification of flavonoid markers for the botanical origin of Eucalyptus honey. Journal of Agricultural and Food Chemistry 48(5): 1498-1502.

Matias, A., Dudar, M., Kauzlaric, J., Frederick, K.A., Fitzpatrick, S. \& Ives, S.J. 2019. Rehydrating efficacy of maple water after exercise-induced dehydration. Journal of the International Society of Sports Nutrition 16(1): 5-17.

Matzinger, O., Schneiter, P. \& Tappy, L. 2002. Effects of fatty acids on exercise plus insulin-induced glucose utilization in trained and sedentary subjects. American Journal of Physiology-Endocrinology and Metabolism 282(1): E125-E131.

Maughan, R.J. \& Shirreffs, S.M. 2004. Rehydration and recovery after exercise. Science \& Sports 19(5): 234-238.

Maughan, R.J., Leiper, J.B. \& Shirreffs, S.M. 1996. Restoration of fluid balance after exercise-induced dehydration: Effects of food and fluid intake. European Journal of Applied Physiology and Occupational Physiology 73(3-4): 317-325.

McArdle, W.D., Katch, F.I. \& Katch, V.L. 2010. Exercise Physiology: Nutrition, Energy, and Human Performance. Philadelphia, Pennsylvania: Lippincott Williams \& Wilkins.

McGawley, K. 2017. The reliability and validity of a four-minute running time-trial in assessing $\mathrm{VO}_{2 \max }$ and performance. Frontiers in Physiology 8(270): 1-9.

Muhammad, Z.S., Chen, C.K. \& Sirajudeen, K.N.S. 2018. Effects of heat on oxidative stress marker (reduced to oxidized glutathione ratio), selected physiological responses and running time-trial performance among recreational athletes. International Journal of Public Health and Clinical Sciences 5(2): 102-119.

Murray, R. 1996. Dehydration, hyperthermia, and athletes: Science and practice. Journal of Athletic Training 31(3): 248-252.

Niksefat, M., Akbari-Fakhrabadi, M., Mousavi, Z., Ziaee, V., Fallah, J. \& Memari, A.H. 2019. Yogurt drink effectively rehydrates athletes after a strenuous exercise session. Acta Medica Bulgarica 46(1): 43-49.

Ooi, F.K., Rabindarjeet, S., Roland, G.S., Ang, B.S. \& Jamalullail, S. 2001. Effects of a herbal ergogenic drink on cycling performance in young cyclists. Malaysian Journal of Nutrition 7(1\&2): 33-40.

Ping, F.W.C., Chen, C.K., Ooi, F.K. \& Mohamed, M. 2018. Effects of bee bread supplementation on endurance running performance and total antioxidant status in recreational athletes. International Journal of Applied Research in Natural Products 11(1): 17-23.

Randle, P.J., Garland, P.B., Hales, C.N. \& Newsholme, E.A. 1963. The glucose-fatty acid cycle. Its role in insulin sensitivity and the metabolic disturbances of diabetes mellitus. The Lancet 281(7285): 785-789.

Saat, M., Singh, R., Sirisinghe, R.G. \& Nawawi, M. 2002. Rehydration after exercise with fresh young coconut water, carbohydrate-electrolyte beverage and plain water. Journal of Physiological Anthropology and Applied Human Science 21(2): 93-104.

Saunders, M.J. 2007. Coingestion of carbohydrate-protein during endurance exercise: Influence on performance and 
recovery. International Journal of Sport Nutrition and Exercise Metabolism 17(s1): S87-S103.

Saunders, M.J., Luden, N.D. \& Herrick, J.E. 2007. Consumption of an oral carbohydrate-protein gel improves cycling endurance and prevents postexercise muscle damage. Journal of Strength and Conditioning Research 21(3): 678-684.

Saunders, M.J., Kane, M.D. \& Todd, M.K. 2004. Effects of a carbohydrate-protein beverage on cycling endurance and muscle damage. Medicine \& Science in Sports \& Exercise 36(7): 1233-1238

Saxena, S., Gautam, S. \& Sharma, A. 2010. Physical, biochemical and antioxidant properties of some Indian honeys. Food Chemistry 118(2): 391-397.

Sidossis, L.S., Wolfe, R.R. \& Coggan, A.R. 1998. Regulation of fatty acid oxidation in untrained vs. trained men during exercise. American Journal of Physiology-Endocrinology and Metabolism 274(3): E510-E515.

Singh, R. 2003. Fluid balance and exercise performance. Malaysian Journal of Nutrition 9(1): 53-74

Takamata, A., Nagashima, K., Nose, H. \& Morimoto, T. 1998. Role of plasma osmolality in the delayed onset of thermal cutaneous vasodilation during exercise in humans. American Journal of Physiology-Regulatory, Integrative and Comparative Physiology 275(1): R286-R290.

Tremblay, M.S., Copeland, J.L. \& Van-Helder, W. 2004. Effect of training status and exercise mode on endogenous steroid hormones in men. Journal of Applied Physiology 96(2): 531-539.

Tsintzas, K. \& Williams, C. 1998. Human muscle glycogen metabolism during exercise. Sports Medicine 25(1): 7-23.

Van Aggel-Leijssen, D.P., Saris, W.H., Wagenmakers, A.J., Senden, J.M. \& Van Baak, M.A. 2002. Effect of exercise training at different intensities on fat metabolism of obese men. Journal of Applied Physiology 92(3): 1300-1309.

van Beaumont, W., Underkofler, S. \& van Beaumont, S. 1981. Erythrocyte volume, plasma volume, and acid-base changes in exercise and heat dehydration. Journal of Applied Physiology 50(6): 1255-1262.
Wee, S.L., Williams, C., Gray, S. \& Horabin, J. 1999. Influence of high and low glycemic index meals on endurance running capacity. Medicine and Science in Sports \& Exercise 31(3): 393-399.

Wigernaes, I., Stromme, S.B. \& Hostmark, A.T. 2000. Active recovery counteracts the post-exercise rise in plasma-free fatty acids. International Journal of Sport Nutrition and Exercise Metabolism 10(4): 404-414.

Williams, M.B., Raven, P.B., Fogt, D.L. \& Ivy, J.L. 2003. Effects of recovery beverages on glycogen restoration and endurance exercise performance. The Journal of Strength \& Conditioning Research 17(1): 12-19.

Wilmore, J.H., Costill, D.L. \& Kenney, W.L. 2008. Physiological of Sports and Exercise Science. Champaign, Illinois: Human Kinetics.

Wilmore, J.H., Morton, A.R., Gilbey, H.J. \& Wood, R.J. 1998. Role of taste preference on fluid intake during and after 90 min of running at $60 \%$ of $\mathrm{VO}_{2 \max }$ in the heat. Medicine and Science in Sports \& Exercise 30(4): 587-595.

Aidi-Naim Mohamad Samsani, Foong Kiew Ooi*, Chee Keong Chen \& Mohamed Saat Ismail

Sports Science Unit

School of Medical Sciences

Universiti Sains Malaysia

16150 Kubang Kerian, Kelantan Darul Naim

Malaysia

Foong Kiew Ooi*, Chee Keong Chen \& Mohamed Saat Ismail Exercise and Sports Science Programme

School of Health Sciences

Universiti Sains Malaysia

16150 Kubang Kerian, Kelantan Darul Naim

Malaysia

*Corresponding author; email: fkooi@usm.my

Received: 4 June 2020

Accepted: 15 December 2020 